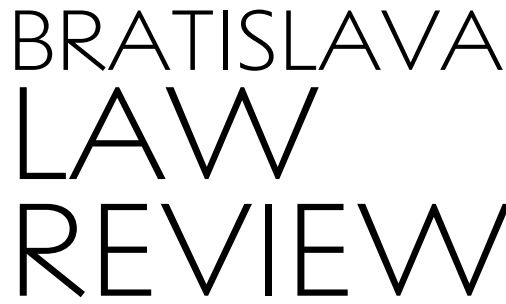

PUBLISHED BY

THE FACULTY OF LAW, COMENIUS UNIVERSITY IN BRATISLAVA

\title{
DO THE NEW PEACE AGREEMENTS BETWEEN ISRAEL AND THE GULF STATES SET A "HONEY TRAP" FOR ISRAEL?
}

/ Nellie Munin

\author{
Nellie Munin LLD, Advocate; Associate \\ Professor and member of the \\ founding faculty, the law school, Zefat \\ Academic College, Israel. Former \\ Minister of Economic Affairs in the \\ Israeli Mission to the EU. Former Chief \\ Legal Advisor, State Revenue \\ Administration, the Israeli Ministry of \\ Finance; \\ Nelliemunin@gmail.com \\ ORCID: 0000-0002-9383-9037
}

Submitted: 24 September 2020

Accepted: 17 October 2020

Published: 31 December 2020

\begin{abstract}
This article examines whether the recent peace agreements, signed between Israel and the Gulf states: The United Arab Emirates and Bahrain in September 2020, form a 'honey trap', meant to use the economic benefits they offer as leverage to affect Israel's political position towards the Middle East conflict. Recalling that the EU exercises such an approach for many years, the article tries to assess its current and potential effectiveness to the parties involved.
\end{abstract}

Key words: Israel; EU; Gulf states; economic benefits; Israeli-Palestinian conflict; Public International Law

\section{Suggested citation:}

Munin, N. (2020). Do The New Peace Agreements Between Israel and the Gulf States Set a "Honey Trap" for Israel? Bratislava Law Review, 4(2), 95-110. https://doi.org/10.46282/blr.2020.4.2.206

\section{INTRODUCTION}

Back in 2003 I wrote an article titled "the honey trap" (see Munin, 2003), suggesting that the EU uses its economic importance to Israel and the latter's keenness to deepen their economic bond, as leverage to try changing Israel's approach regarding its ongoing conflict with the Palestinian people.

This EU approach is not applied only to Israel. It is part of its broader "normative power" approach, or "carrot and stickism" (Manners, 2002) well established in literature, aiming at positioning the EU as a global political and economic player.

Theoretically, Israel should be particularly sensitive to this approach, due to its situs and market's unique characteristics. Pragmatically, however, this EU approach towards Israel seems to yield only limited results.

Since Israel's establishment, in 1948, the Arab states opted for a different approach to the Middle East conflict, refraining from any political or economic contact with Israel, at least formally, believing that this is an effective way to support the Palestinian side of the conflict. Throughout the years, this approach proved to be ineffective, ${ }^{1}$ neither making Israel change its position regarding the conflict, nor

\footnotetext{
1 UAE's minister of state, Anwar Gargash, openly admitted in a Zoom discussion with the American Jewish Committee (AJC) that the detachment approach led the Arab states nowhere (see Shery, 2020).
} 
contributing to its ending. In the 1990's Egypt ${ }^{2}$ and Jordan ${ }^{3}$ changed their positions, concluding peace agreements with Israel. Although peace with both these states is still considered to be "cold", it facilitates certain necessary regional political and economic collaboration, ${ }^{4}$ offering Egypt and Jordan some leverage for interference in the IsraeliPalestinian conflict. It also sends an indirect message to the Palestinian people that they are expected to follow the same path.

Egypt and Jordan - as well as Syria and Lebanon which did not sign peace agreements with Israel - share with it mutual borders. Attempting to help Palestinians, all participated in previous wars and lost territories which were captured by Israel. Their interest to conclude peace agreements with Israel thus involved (in the cases of Egypt and Jordan) or still involves (in the cases of Syria and Lebanon) a desire to regain these territories. Consequently, the terms of such peace agreements are subject to strong political domestic controversies in these countries, and even more so in Israel, which is expected to withdraw these territories in return for peace.

This consideration is irrelevant to the Gulf states situated thousands of kilometres away from the territories in conflict. They were never directly involved in hostilities emanating from the Israeli-Palestinian conflict. They refrained from official relations with Israel, not to protect their own interests, but rather to express identification with the Palestinians. Unofficially, limited economic and political relations between Israel and these states have been in existence for many years. Consequently, formal peace made with them does not face strong domestic political objections in any of the parties to these peace agreements. ${ }^{5}$

In recent years, the Gulf states' motivation to refrain from official connections with Israel was eroded in two major aspects:

- A growing domestic need to enhance economic collaboration with Israel - known as a global leader in high tech and advanced technologies - realizing the ongoing decline in economic importance of the Gulf states' major source of capital: oil (Rapier, 2020), broadly replaced with solar, wind and other environment-friendly sources of energy.

- The growing frustration from the stagnant Palestinian position and the abuse for hostile purposes of huge amounts of money (e.g., Pardos and Blanchard, 2004; FATF, 2020), ${ }^{6}$ including sums contributed by the Gulf states and others to develop the Palestinian economy.

Both these aspects, enhanced by some US's incentives, ${ }^{7}$ partly explain the recent shift of position which led to a conclusion of two new peace agreements, one between Israel and the United Arab Emirates (UAE) and the other between Israel and Bahrein, in

\footnotetext{
2 See the full text of the agreement in Israel Ministry of Foreign Affairs (2013a).

${ }^{3}$ See the full text of the agreement in Israel Ministry of Foreign Affairs (2013b).

${ }^{4}$ In 2018 the total scope of Israeli imports from Egypt was 111 million \$ and the total scope of Israeli exports to it was 72 million \$ (Tel Aviv and Center Chambers of Commerce, 2019). In 2019, the total scope of Israeli imports from Jordan was 99.2 million \$ and the total scope of Israeli exports to it was 8.8 million \$. Israeli Central Bureau of Statistics, 2020).

${ }^{5}$ In Israel, it did not encounter any objection. In the Gulf states, some public protest was witnessed, but its scale was quite limited (Frisch, 2020).

${ }^{6}$ See also Official NGO Monitor website, available at: https://www.ngomonitor.org.il/search/?q=+terror+financing (accessed on 22.11.2020).

7 US's president Donald Trump promised in his first election campaign to bring peace to the Middle East. In January 2020 his administration initiated a peace plan for the region, titled Peace to Prosperity. See the full text in WhiteHouse.gov (2020). However, since this program did not seem to be accepted by the Palestinians, and Trump has an urgent need to "deliver" before the coming elections Trump, who was interested to enhance alternative peace agreements, suggested the Gulf states incentives such as the sale of F-35 jet airplanes to the United Arab Emirates (Globes, 2020).
} 
September 15, 2020. According to US's President Trump, some five other Gulf states are expected to follow soon (Harkov 2020).

While this change of approach bears obvious political implications, it also opens the way for enhanced economic collaboration between Israel and the Gulf states, which was not possible previously. This collaboration might lead to a growing dependence of the Israeli economy ${ }^{8}$ on these states, implying a political leverage over Israel, which did not exist hitherto.

This article examines whether, or to what extent, the new Gulf states' approach corresponds to EU's long-lasting "honey trap" approach towards Israel. Analysing the merits and limits of EU's approach during the years it is applied to Israel, the article tries to assess the potential leverage created by the new Gulf states' approach towards Israel, in both economic and political terms. The first section explains why Israel is potentially so sensitive to subjecting economic benefits to political dictation by its trade partners. The second section introduces EU's "normative power" and 'soft power' approaches, and their application to Israel. The third section analyses the new peace agreements between Israel, the UAE and Bahrein, assessing the potential economic leverage they suggest in comparison to that of the EU. The fourth section concludes.

\section{ISRAEL'S VULNERABLE POSITION AS A GLOBAL TRADER}

Israel is a relatively small country, ${ }^{9}$ situated in a hostile neighbourhood. Although mostly surrounded by land, it effectively feels like an island: land transportation in and out of it is very limited, due to its conflict with most of its neighbouring countries. For the same reason, its major trade and political partners are geographically remote.

Due to Israel's small size and problematic situs, the Israeli economy heavily relies on international trade, ${ }^{10}$ to exhaust its comparative advantages ${ }^{11}$ and economies of scale $^{12}$ benefits. Moreover, Israel's geographical distance from many potential trade partners dictates its reliance on the EU - its geographically closest ${ }^{13}$ trade partner outside the region - to save expensive shipment costs to remote destinations, and enable trade in perishable goods, such as fresh foods, flowers and livestock as well as in fragile goods, that could barely last long shipments.

Israel's major economic partners are the EU ${ }^{14}$ and the US. ${ }^{15}$

The Israeli market is thus very vulnerable to lack or decline of external trade, emanating either from global drawbacks such as the current COVID-19 pandemic, or from potential political pressures assumed by its trade partners.

\footnotetext{
${ }^{8}$ Israeli politicians who commented on these agreements expressed hopes for intensive investments from these Gulf states in the Israeli market, to help it recover the current economic crisis caused by COVID-19. See, e.g. Odenheimer (2020).

9 Israel's territory spreads over 21,640 Square KM (see Worldmeter, 2020). It is ranked 153 in terms of territory's size globally. Its population comprises some 9.2 million citizens (Israel Today, 2020).

${ }^{10}$ Imports and exports form almost $60 \%$ of Israel's GDP (Israeli Central Bureau of Statistics, 2020a).

11 Comparative advantage is a notion attributed to the economist David Ricardo who, in the $19^{\text {th }}$ century, suggested that each country should expertise in producing goods or services which it can produce in the lowest comparative cost, and buy other products and services from countries producing them in the cheapest comparative cost, to maximize its profits

12 Economies of scale is an economic principle suggesting that the cost per unit of output decreases as the scale of production (and sales) increases.

13 The Cypriot border, serving as an EU gate, is only $300 \mathrm{~km}$ far from Israel.

14 In 2019, Israeli exports to the EU exceeded 17.3 bn \$ while its imports from the EU exceeded 27.6 bn $\$$ (Israeli Central Bureau of Statistics, 2020b).

15 In 2019, Israeli exports to the US exceeded 15.9 bn $\$$ while its imports from the US exceeded 11.7 bn $\$$ (Israeli Central Bureau of Statistics, 2020c).
} 
Until the 1990's, Israel tended towards a protectionist approach, to allow its infant industries to grow. In recent decades the decisiveness of international trade to the development of the Israeli mature economy is broadly realized.

Over the years, Israel took unilateral, regional and multilateral steps to facilitate international trade. In the multilateral sphere, it joined the GATT ${ }^{16}$ in 1961 and the WTO ${ }^{17}$ upon its establishment, in 1995.

Israel established a network of regional and bilateral trade agreements, ${ }^{18}$ complementing the multilateral setting by allowing more specific, custom-made adjustments between their parties. Unilateral measures are taken from time to time, to fine-tune the balance between the Israeli market's domestic needs and its external trade. $^{19}$

In previous decades Israeli decision makers believed that the WTO system would suffice to cover most Israel's trade concerns. Thus, insufficient efforts were invested in the bilateral and regional spheres. The deadlock the WTO experiences in recent years ${ }^{20}$ illuminated the limits of Israel's relatively small bilateral and regional network of agreements. In recent years more efforts have been invested in broadening this network, but being time and effort consuming processes, negotiations advance slowly. Moreover, while trade in services is the source for more than $70 \%$ of Israel's GDP, it is yet uncovered by most of Israel's regional and bilateral trade agreements. ${ }^{21}$

The time and effort consuming processes of negotiating international trade agreements implies that Israeli decision makers have to prioritise their limited resources. That process is further slowed down by Israeli leaders' hesitation between reinforcing relations with the "old world" giants, i.e. the US and the EU which are Israel's major current trade - and political ${ }^{22}$ - partners, and opting for new, promising domains by intensifying Israel's trade contacts with "new world" players, i.e. Far East emerging powers, such as China and India. This hesitation is also reflected in the public and business community discourse in Israel. However, Israel's list of the currently negotiated trade agreements seems to mark a growing realization of such variety's importance.

The recent COVID-19 pandemic offered an interesting setting to test another feature underlining (and limiting) Israel's global trade policy. Israeli decision makers

16 GATT - the General Agreement on Tariffs and Trade. See full text in: https://www.wto.org/english/docs_e/legal_e/gatt47.pdf (accessed on 22.11.2020).

17 WTO - the World Trade Organization, now encompassing 164 member states. See more details in: www.wto.org (accessed on 22.11.2020).

18 Israel has regional trade agreements with the US, Canada, Mexico, MERCOSUR, Columbia, Panama, the EU, EFTA, the UK (to be effectuated after the Brexit), Turkey, Ukraine, Egypt and Jordan. Currently, Israel negotiates additional trade agreements with South Korea, India, Vietnam, China, the Euro-Asian Union and Guatemala (The Israeli Ministry of Economy, 2020)

19 In 1991 Israel unilaterally liberalized trade in certain sectors, including lumber wood, shoes and textiles. Since then, unilateral liberalization was used to enhance competition and reduce prices, e.g. regarding certain cheeses in recent years, or to relieve seasonal lacks of certain products, e.g. eggs in spring 2020.

20 WTO's stagnation in recent years emanates from several reasons, including disagreement between the US and other member states on nominations of Appellate Body members, and an ongoing disagreement between developed and developing member states on the desired WTO agenda. Consequently, the "Doha Round" that started in 2001 does not reach an end (see Pakpahan, N.D.).

${ }^{21}$ A chapter on trade in services is included in the free trade area agreement concluded with Panama in 2018 (Free Trade Agreement between the State of Israel and the Republic of Panama, 2018). One reason for that situation is, again, Israel's reliance on the multilateral sphere that disappointed: the TISA initiative, which was an attempt that failed to establish a complementary multilateral agreement on trade in services outside the GATS (see European Commission, 2017a). The other reason is a combination of the considerable efforts it requires from Israel and the reluctance of Israel's trade partners to push for it, due to the relatively small size of the Israeli market.

22 Politically, Israel tends to rely more on the US than on the EU. The public opinion in Israel perceives EU's political position as biased in favour of the Palestinians. Thus, it perceives the US as a more honest broker. 
believe that since it is surrounded by hostile neighbours it should maintain some - even uncompetitive - domestic industries, to ensure the supply of basic foods and products in cases of temporary international supplies cut offs. Unfortunately, one such regulated and protected industry: the domestic eggs industry, failed to deliver during the first COVID-19 wave in spring 2020 (see Munin, 2020).

Currently, Israel is thus a country situated in a hostile neighbourhood that could find itself isolated in terms of international trade in no time, due to political hostilities or international crises such as COVID-19. To exhaust its economic potential, it heavily relies on international trade. Due to years of strategic miscalculation, its current network of regional and bilateral trade agreements is quite limited. Consequently, the Israeli economy heavily relies on the EU and the US, its major trade partners. This reliance is further reinforced by Israel's political reliance on these two "old world's" superpowers.

These facts may explain Israel's vulnerability to political pressures from its trade partners.

\section{THE EU AND THE "HONEY TRAP" IT SETS}

The EU, the world's largest trade block, has been long using its economic power to affect the political agenda of its partners, by exercising what is broadly recognized by the literature as 'normative power' (see for example Duchêne, 1972; Galtung, 1073; Diez, 2013; Gordon and Pardo, 2015) - the 'export' of EU legal norms to other countries, e.g. by mutual international agreements, and other forms of "soft power" (e. g., Nye, 2009; Smith, 2006; Ociepka, 2013) - the power to politically convince the others to adopt behaviour, positions, norms or agendas shared by the EU.

In the Mediterranean region context, this policy has been reinforced since mid1990's, with the conclusion of Association agreements between the EU and the Mediterranean countries. These agreements are rooted in the Barcelona Process, ${ }^{23}$ launched at the euphoric time when the "Oslo Agreements" 24 between Israel and the PLO where concluded, and peace in the region seemed to be within reach. The Barcelona process envisioned an adjusted application of the EU model to the Mediterranean region, aiming to establish a network of international trade agreements among the Mediterranean countries, and a complementary network of agreements between them and the EU. While the potential parties where quite reluctant to establish the anticipated regional network of agreements, ${ }^{25}$ most of them (including Israel) concluded Association agreements with the EU.

The EU aims to strengthen its position as a global political and economic player, competing with other global powers, such as the US and China (see European Commission, 2017b, pp. 8-10). It thus desires to portray an international image of a power that could potentially change the position of other players, as well as a guardian of public international law rules and basic rights of the relatively weak parties in international conflicts. The EU is interested in affecting the Middle East, due to its global political and

\footnotetext{
23 Nowadays, the process has melted into the EU's Union for the Mediterranean (UFM) program. See more details in: The Barcelona Process or Euro-Mediterranean Partnership. Available at: https://www.barcelona.com/barcelona_news/the_barcelona_process_or_euro_mediterranean_partnership (accessed on 22.11.2020).

24 The "Oslo Agreements", concluded between Israel and the PLO in 1993 and in 1995, provided for a gradual process of peace building in the region. The process was never completed due the political assassination of the Israeli Prime minister Yitzhak Rabin and the Palestinian hostilities that followed (see Israel Ministry of Foreign Affairs, 2013c).

25 In some cases, due to regional conflicts. In other cases, due to low volumes of trade that did not justify the necessary efforts.
} 
economic importance and geographic proximity (see, e. g., Gomez, 2003; Wolf, 2009; Bicchi, 2010; Pierini, 2020). The Association agreements with the Mediterranean countries facilitate EU's exercise of "normative power" to that extent.

Reflecting EU's vision, all these Association agreements include political references. In the EU-Israel association agreement, ${ }^{26}$ they are embodied in Article 2, subjecting the agreement to mutual respect of shared values, such as democracy and the rule of law, and in Article 3 providing for an ongoing political dialogue between the parties. $^{27}$

Since their conclusion, these Association agreements have underlined EU's attempts to apply its political agenda to the Mediterranean countries including, inter alia, territorial disputes between Turkey and Cyprus over North Cyprus, ${ }^{28}$ Morocco and Spain over Western Sahara, ${ }^{29}$ and Israel and the Palestinian Authority over the 'occupied territories'.

In the latter case, after the conclusion of the Association agreements with Israel (1995) and with the PLO (1997) ${ }^{30}$ the EU started to exclude the territories Israel captured during regional wars from the former Association Agreement's scope of application, contending that these territories are not part of "Israel". ${ }^{31}$ The CJEU addressed this legal and political controversy in two $^{32}$ controversial $^{33}$ rulings, reinforcing this position. Since the CJEU holds the supreme power to interpret EU law, EU member states and institutions follow these rulings closely, applying this interpretation to EU legislation and administrative practices across the board. ${ }^{34}$

This EU approach certainly deprives the disputed territories off the economic benefits embodied in the EU-Israel Association agreement. Attempts to quantify its exact economic effect fail because the situation on the ground is dynamic, but the overall assessment is bearable for Israel. Concerns that other countries may be inspired by the EU to adopt a similar position towards the territories, or rather towards the entire Israeli economy (e.g., Kofman, 2014) did not turn into a broad-scale reality, in the meantime.

While the EU may have drawn some international attention and considerable academic and media attention for taking these steps, reinforcing its desirable international image, they did not change the Israeli position towards the territories.

\footnotetext{
${ }^{26}$ Euro-Mediterranean Agreement Establishing an Association between the European Communities and their Member States, of the one part, and the State of Israel, of the other part, OJ L 147/3 21.06.2000. Available at: https://eeas.europa.eu/archives/delegations/israel/documents/eu_israel/asso_agree_en.pdf (accessed on 22.11.2020)

${ }_{27}$ Such references were not included in the previous free trade area agreement between Israel and the EU of 1975 , which the Association agreement replaced.

${ }^{28}$ Case C-219/98 Regina v. Minister for Agriculture, Fisheries and Food, ex parte S.P. Anastasiou (Pissouri) Ltd. \& Others, EU:C:2000:360 (re North Cyprus). Available at: http://curia.europa.eu/juris/liste.jsf?language=en\&num=C-219/98 (accessed on 22.11.2020).

${ }^{29}$ Case C-104/16 Council v. Front Polisario, judgment of 21 December 2016. Available at: http://curia.europa.eu/juris/liste.jsf?language=en\&num=C-104/16 (accessed on 22.11.2020).

30 See full text in Treaties Office Database (2012).

${ }^{31}$ Simultaneously, they are unable to enjoy the benefits of the EU-PLO Association agreements, since these territories are effectively captured by Israel, exercising its sovereignty on them until the end of the conflict. ${ }^{32}$ C-386/08 Brita GmbH v. Hauptzollamt Hamburg-Hafen, available at: http://curia.europa.eu/juris/document/document.jsf?text=\&docid=72406\&pagelndex=0\&doclang=EN\&mode =Ist\&dir=\&occ=first\&part=1\&cid=4196248 (accessed on 22.11.2020); and Case C-363/18 Organization juive Europeenne, Vignoble Psagot LTD v. Ministre de l'Economie et des Finances, available at: http://curia.europa.eu/juris/liste.jsf?num=C-363/l (accessed on 22.11.2020).

${ }^{33}$ For details on the development of this controversy and the conflicting arguments by the parties, as well as criticism over EU's approach, see: Munin (2011); Munin (2015); Munin and Sitbon (2020).

${ }_{34}$ Brita judgment refers to import duties. Psagot judgment refers to consumer protection. Other fields are covered by EU regulation, e.g., European Commission (2011); European Commission (2013a); European Commission (2013b)
} 
Another way by which the EU assumes pressure on Israel involves its refrainment from updating their Association agreement. The EU-Israel Association agreement was drafted more than 25 years ago. It definitely needs some updating. Thus, for example, it does not cover services, forming source for more than $70 \%$ of both parties GDP. Many provisions in it, allowing for potential collaboration in fields such as transportation, energy, education, immigration etc., that could have yielded economic advantages to both parties, are not realized, or fully exhausted, for political reasons. Although it is hard to assess the economic damage of this reality, it undoubtedly implies substantial economic losses, particularly to the Israeli economy, considerably depending on the EU as its major trade partner. Nevertheless, even this does not persuade Israel to change its approach towards the regional conflict.

In times of regional hostilities, e.g. military operations Israel conducted to put a stop to constant rocket shooting from Gaza Strip, some EU members suggested to rely on Article 2 of EU-Israel Association agreement, referring to mutual shared values, to suspend the entire agreement with Israel, for allegedly not respecting these values. A similar suggestion was recently invoked in the context of Israel's unilateral annexation plan (e.g., European Coordination of Committees and Associations for Palestine, 2015; European Parliament, 2014). Eventually, other member states undermined these initiatives, but this is another pending potential EU threat. ${ }^{35}$

The reason Israel does not change its position despite these strong pressures is that the territories' status is a core issue in Israeli politics, with some believing that it may affect Israel's very existence. Namely, it is too substantial to be given up for any economic benefits at stake.

Thus, the 'honey trap' the EU created has only a limited effect.

Yet another limit to EU's 'honey trap' lies in its own economic interests: when these are at stake, the EU would enhance connections with Israel, ignoring differences in their political positions. One good example is the ongoing collaboration between Israel and the EU regarding R\&D ventures, now under the auspice of Horizon 2020. ${ }^{36}$ Israel's ongoing active participation in this programme and in its preceding "Framework Programmes" was never threatened by the EU, because it serves well EU's interests. ${ }^{37}$

\section{DO THE GULF STATES CREATE THEIR OWN “HONEY TRAP”?}

\subsection{The Negotiations: Assuming "Soft Power"?}

According to negotiators, the peace agreements recently concluded between Israel, the UAE and Bahrein result from long years' efforts (Eichner, 2020). Moreover, the agreements bring into the open unofficial security and intelligence, economic and trade collaboration as well as a public inter-religious dialogue including Jews, Christians and Muslims that has already been taking place between Israel and these states.

In January 2020, the US published its peace initiative for the Mediterranean region. The plan supported the application of Israeli sovereignty to $30 \%$ of Judea and Samaria (part of the territories occupied in 1967). In return, Israel was required to agree

\footnotetext{
${ }^{35}$ Recently, this threat was invoked regarding the planned annexation of territories. According to the press, Sweden, Luxembourg and Ireland supported this initiative, while Hungary, Romania, Bulgaria and the Czech Republic where ready to Block it (Kahana and ILH Staff, 2020).

36 See details and statistics about the Israeli participation in this program in Israel-Europe Research \& Innovation Directorate (2020).

${ }^{37}$ On the contrary: in one of the outbursts of controversy between the EU and Israel, in 2013, Israeli Prime Minister Netanyahu threatened that due to EU's approach regarding the territories Israel would not join Horizon 2020. This threat was later removed after mutual negotiations (European Commission, 2013c).
} 
to the establishment of a Palestinian state with limited sovereign powers, supposing the Palestinians meet certain terms such as dealing with terror, giving up the right of return, stopping activities against Israel in international forums, recognizing Israel as a Jewish state that has a right to exist, etc. The programme did not subject the annexation of the territories by Israel to Palestinian agreement. Following explicit Palestinian rejection of this plan, the Israeli Prime Minister Netanyahu announced that Israel considers unilateral annexation of captured territories in the West Bank. ${ }^{38}$ The deadline for this annexation was set for July 1st, 2020. This announcement triggered a broad public discourse in Israel, both in the media and in academic channels (e.g., Dekel and Shusterman, 2020; Commanders for Israel's Security in partnership with Israel Policy Forum, 2018). In June 2020 Netanyahu announced that to avoid broad global opposition, following thorough examination by domestic expert teams nominated to recommend further steps, the Israeli government considered to unilaterally annex only part of the originally planned territories. It was estimated that EU warnings contributed to this shift of position (Bersky and Kutz, 2020). Finally, Israel agreed to refrain from unilateral annexation altogether, at least for the time being, in return to the peace agreements with the UAE and Bahrein. This sequence of events, reported by the media, cannot indicate whether, or to what extent, the intention for unilateral annexation of all or part of the West Bank territories was serious, or rather a well-planned, coordinated device of misinformation, intended to draw the global and local attention from the last phase of the negotiations, or to create the impression of an American/Arab political achievement.

If Israel swaps a serious intention to unilaterally annex the territories with the peace agreements, the potential economic and political benefits such agreements offer may have served as "honey traps" for Israel, set either by the Gulf states, ${ }^{39}$ the US or both. However, lack of sufficient information makes it hard to draw an evident conclusion. The political spin option cannot be completely ruled out, taking into account Israeli leaders' awareness of the possible far-reaching international and domestic political implications of such steps, on the one hand, and the contemporary shaky political statuses of President Trump and Prime Minister Netanyahu, on the other.

Gulf states leaders contend that in the negotiations process they succeeded to convince Israel to opt for normalization rather than annexation that would lead to severe regional, and maybe global, results. If this is true, these states exercised on Israel "soft power", obviously encouraged by the US - that was reinforced by the Israeli expectation for the political and economic benefits this move may yield, in its relations with the Gulf states and the US, as well as for a broader scale positive effects on its status in the region as well as on its global image.

\subsection{The Agreements}

\subsubsection{UAE-Israel Agreement}

The UAE is an emerging player in the Arab world. In recent years it plays a dominant role in regional politics. Its small army, considered to be the most skilled and

\footnotetext{
38 Of the territories Israel has captured, some were withdrawn due to the peace agreements with Jordan and Egypt. The Gaza strip was unilaterally withdrawn while East Jerusalem and the Golan Heights were unilaterally annexed by Israeli laws. The territories Netanyahu addressed are situated in Judea and Samaria.

39 Yousef El Otaiba, UAE's secretary of State and its Ambassador to the US described, in an interview he gave, a process by which the Gulf states convinced Israel to give up annexation and opt for normalization in the region, explaining to its leaders the destructive potential of this step, exercising trust-building gestures such as establishing "Abraham Family's House" in Abu Dabi, which would include a church, a musk and a synagogue; establishing a kosher catering in Dubai, and offering Israel more security and direct connections.
} 
equipped army among the Arab states, is involved in fighting in Yamen, Libya and Afghanistan. The ratio between its small population (only one million nationals, nine million citizens) and its great oil reserves (about 100 million proved barrels) turns it into one of the richest countries in the world. Experts assess that UAE's motivation to conclude the agreement with Israel lies in its leader's desire to improve its international image, eroded by UAE's military involvement in Yamen, and strengthen its relations with the US, which offers the UAE certain guarantees and access to advanced weapons. Indirectly, this step supported US's president Trump in the last elections, an interest shared by UAE's leader Bin Zaid (Gozansky, 2020). This opinion may raise a doubt regarding UAE's "honey trap" motivation, suggesting that its major motivation to sign this agreement barely involves Israel (with which economic and political relations existed anyway). At the same time, however, affecting the Israeli position regarding the conflict may contribute to UAE's regional and global image restoration.

The Agreement's Text:

The Treaty of Peace, Diplomatic Relations and Full Normalization Between the United Arab Emirates and the State of Israel, concluded in September 15, 2020 (see full text in TOI STAFF, 2020), includes some elements that may indicate a "honey trap".

Similarly to EU-Israel Association agreement, it includes a political context, obtained by references to the Charter of the United Nations (Article 2), a mutual commitment to peace and stability in the entire Middle East, a commitment for regular mutual dialogue (Article 4), and a mutual commitment to cooperate with the US and others to launch a "strategic agenda for the Middle East" (Article 7).

Another resemblance to the EU-Israel Association agreement lies in a list of potential fields of economic collaboration, which should be developed into detailed agreements (Article 5). This list includes finance and investment; civil aviation; visas and consular services; innovation, trade and economic relations; healthcare - science, technology and peaceful uses of outer-space; tourism, culture and sport; energy environment- education; maritime arrangements; telecommunications and post; agriculture and food security; water; legal cooperation.

The language of this framework agreement indicates that the parties expect to develop these specific economic collaboration agreements that would turn peace into a detailed reality, as soon as possible, providing: "Any such agreements concluded before the entry into force of this Treaty shall enter into effect with the entry into force of this Treaty unless otherwise stipulated therein. Agreed principles for cooperation in specific spheres are annexed to this Treaty and form an integral part thereof." [Emphasis added].

However, bearing in mind the fact that similar potential provisions, included in EU-Israel Association agreement 25 years ago are still not realized due to political disagreement about the Middle East conflict, and the 'cold' peace with Egypt and Jordan, one may foresee how such provisions may function as a "honey trap", either by immediate realization leading to greater economic dependence or by avoiding it, on political grounds. The Horizon 2020 example illustrates that the choice between these two alternatives might depend on the urgency of the Gulf states' need to enjoy connections with Israel and the fields in which such urgency exists.

Yediot Aharonot, 12 June 2020. Available at: https://www.ynet.co.il/articles/0,7340,L-5746959,00.html (accessed on 22.11.2020). Some assess that without a determinant declaration by UAE's leader, Sheikh Mohammed bin Zayed, supporting Jordan's position against the annexation, this normalization process would not have been launched at this timing (see Gozansky, 2020). 


\subsubsection{Bahrein-Israel Agreement}

Bahrein is a tiny country, with a territory of only 780 Square KM. Nevertheless, in terms of richness it is graded 33 in the world. $85 \%$ of its incomes emanate from oil. Bahrein also enjoys very strong connections with the US, equipping its army with modern weapons. This is particularly important due to constant threats it suffers from neighbouring Iran (Gozansky, 2012). Bahrein lifted its boycott on Israel back in 2005 and since then held unofficial, visible political connections with Israel.

Bahrein seems to have joined the peace initiative in the last moment. Thus, at the time this article was written the parties signed only a declaration of peace, ${ }^{40}$ rather than an agreement.

This declaration also reflects an equilibrium between, on the one hand, a mutual commitment to peace and security in the region, including an explicit commitment to continue "the efforts to achieve a just, comprehensive, and enduring resolution of the Israeli-Palestinian conflict." On the other hand - the "carrot": a mutual commitment to "seek agreement in the coming weeks regarding investment, tourism, direct flights, security, telecommunications, technology, energy, healthcare, culture, the environment, and other areas of mutual benefit, as well as reaching agreement on the reciprocal reopening of embassies."

Such future detailed agreements could shed more light on the balance of interests the parties would choose to adopt, and the leverage of political influence it might create. In this case, too, it remains to be seen how quickly detailed agreements would be signed, to conclude whether their very signature is used as a means of political pressure on Israel.

\section{CONCLUSION}

This article examined the presumption that the new peace agreements concluded between Israel and two Gulf states: UAE and Bahrein, form "honey traps" meant to give the latter a leverage to change Israel's approach towards its ongoing conflict with the Palestinians, in return to economic and political benefits. This presumption was inspired by UAE leaders' admissions that they changed their position towards Israel since the detachment approach did not yield the expected fruits.

However, a thorough analysis of the current available texts which were signed in Washington in September 15, 2020, and the surrounding circumstances does not seem to lead to a clear conclusion.

In terms of motivation, it is unclear whether the Gulf states at stake share EU's motivation. Their willingness to engage in these agreements could be totally different, as suggested. In addition, some open ends make it difficult to complete the assessment at this point in time:

Trade volume and essence: one open question refers to the potential economic effect of these new alliances on the Israeli economy. While the EU, exercising such a 'honey trap' on Israel, is its major trade partner, it is yet unclear to what extent the Israeli economy may find itself depending on Gulf states' investments or on trade with these countries. 'Honey traps' effectiveness rely on substantial trade/investments volumes or on unique, indispensable aspects of trade associated with a certain trade partner.

Lack of Details: the details of any future agreement between the parties are yet unknown. The current documents signed only form frameworks for the mutual working out of such future, detailed agreements.

${ }^{40}$ See full text of the declaration in Landau (2020). 
The time frame is also decisive: if detailed agreements, covering all listed issues, are signed in a short while, the potential of delaying them for decades to assume pressure, as done by the EU, would be undermined. However, suspending the trade they would facilitate may serve as an alternative leverage.

Time will thus tell what the effect of these agreements would be. If other Gulf states would join this initiative, they might become part of a more decisive trade block, bearing a greater economic potential - and consequently a greater potential political power which could assume pressure on Israel to change its approach towards the conflict.

The fact that even EU's real effect on the Israeli position towards the conflict is quite limited, could indicate the limits of any intended "honey trap" the Gulf states may expect. Having said that, Israel should not, however, rule out the possibility that the EU, the US and Gulf states may in the future join hands to change Israel's political position towards the conflict, imposing on it joined economic pressure.

\section{BIBLIOGRAPHY:}

Bersky, A. R. and Kutz, G. (2020). The Upcoming Plan: Applying Israeli Sovereignty Only to Jewish Settlements in Judea and Samaria. Maariv, 12 June 2020 [Hebrew]. Available at: https://www.maariv.co.il/news/politics/Article-770949 (accessed on 22.11.2020).

Bicchi, F. (2010). Dilemmas of Implementation: EU Democracy Assistance in the Mediterranean. Democratization, 17(5), 976-996. DOI: https://doi.org/10.1080/13510347.2010.501181.

Case C-104/16 Council v. Front Polisario, judgment of 21 December 2016. Available at: http://curia.europa.eu/juris/liste.jsf?language=en\&num=C-104/16 (accessed on 22.11.2020).

Case C-219/98 Regina v. Minister for Agriculture, Fisheries and Food, ex parte S.P. Anastasiou (Pissouri) Ltd. \& Others, EU:C:2000:360 (re North Cyprus). Available at: http://curia.europa.eu/juris/liste.jsf?language=en\&num=C-219/98 (accessed on 22.11.2020).

Case C-363/18 Organization juive Europeenne, Vignoble Psagot LTD v. Ministre de l'Economie et des Finances. Available at:

http://curia.europa.eu/juris/liste.jsf?num=C-363/I (accessed on 22.11.2020).

Case C-386/08 Brita GmbH v. Hauptzollamt Hamburg-Hafen. Available at: http://curia.europa.eu/juris/document/document.jsf?text=\&docid=72406\&pagel ndex $=0 \&$ doclang $=E N \&$ mode $=I$ st $\&$ dir $=\& o c c=$ first $\&$ part $=1 \&$ cid $=4196248$ (accessed on 22.11.2020).

Commanders for Israel's Security in partnership with Israel Policy Forum (2018). Ramifications of West Bank Annexation: Security and Beyond. Available at: https://israelpolicyforum.org/wp-content/uploads/2015/05/AnnexationSummary-English-V1.pdf (accessed on 22.11.2020).

Dekel, U. and Shusterman, N. (2020). Annexing Judea and Samaria: Where Would it Lead? INSS, 10 June 2020. [Hebrew]. Available at: https://www.inss.org.il/he/publication/annexation-convention-summary/ (accessed on 22.11.2020).

Diez, T. (2013). Normative Power as Hegemony. Cooperation and Conflict, 48(2), special Issue on Normative Power Europe (June 2013), 194-210. DOI: https://doi.org/10.1177/0010836713485387.

Duchêne, F. (1972). Europe's Role in World Peace. In: Mayne, R. (ed.) Europe Tomorrow: Sixteen Europeans Look Ahead (pp. 32-47). London: Fontana. 
Eichner, I. (2020). Head of the Mosad will Soon Fly to UAE to Discuss the Peace Agreement's Details. Ynet, 14 August 2020 [Hebrew]. Available at: https://www.ynet.co.il/news/article/rJCLcn7GD (accessed on 22.11.2020).

European Commission (2011). Commission decision of 31 January 2011 pursuant to Directive 95/46/EC of the European Parliament and of the Council on the adequate protection of personal data by the State of Israel with regard to automated processing of personal data. (OJ L 27/39), Brussels, Belgium.

European Commission (2013a). 2013/C205/05 Guidelines on the Eligibility of Israeli Entities in the territories Occupied by Israel since June 1967 for grants, prizes, and financial instruments funded by the EU from 2014 onwards. (OJ C 205/5), Brussels, Belgium.

European Commission (2013b). Commission implementing regulation (EU) No. 594/2013 of 21 June 2013 amending implementing regulation (EU) No.

$543 / 2011$ as regards marketing standards in the fruit and vegetables sector and correcting that implementing regulation, 22 June 2013 (OJ L 170/43), Brussels, Belgium.

European Commission (2013c). Israel Will Take Part in Horizon 2020. Available at: https://cordis.europa.eu/article/id/36298-israel-will-take-part-in-horizon-2020 (accessed on 22.11.2020).

European Commission (2017a). Trade in Services Agreement (TiSA). Available at: https://ec.europa.eu/trade/policy/in-focus/tisa/ (accessed on 22.11.2020).

European Commission (2017b). The White Paper on the Future of Europe: Reflections and Scenarios for the EU27 by 2025. Available at: https://ec.europa.eu/commission/sites/betapolitical/files/white_paper_on_the_future_of_europe_en.pdf (accessed on 22.11.2020).

European Coordination of Committees and Associations for Palestine (2015). Suspend EU-Israel Treaty, 63 MEPs Say. Available at:

http://www.eccpalestine.org/suspend-eu-israel-treaty-63-meps-say/ (accessed on 22.11.2020).

European Parliament (2014). Parliamentary Questions: 23 October 2014. Subject: Suspension of the EU-Israel Association Agreement. Available at: https://www.europarl.europa.eu/doceo/document//E-8-2014-008366_EN.html (accessed on 22.11.2020).

FATF (2020). Anti-Money Laundering and Counter-Terrorist Financial Measures United Arab Emirates, Mutual Evaluation Report, April 2020. Available at: https://www.fatf-gafi.org/media/fatf/documents/reports/mer4/MutualEvaluation-Report-United-Arab-Emirates-2020.pdf (accessed on 22.11.2020).

Free Trade Agreement between the State of Israel and the Republic of Panama (2018). Available at: http://www.economy.gov.il/InternationalAffairs/TradePolicyAndAgreements/Bila teralAgreementsDivision/Panama/FreeTrade/israel-panama-agreement.pdf (accessed on 22.11.2020).

Frisch, H. (2020). The Israel - UAE Agreement's Greatest Achievement: Little Arab Protest. The Begin-Sadat (BESA) Center for Strategic Studies, BESA Center Perspectives Paper No. 1,729, September 3, 2020. Available at: https://besacenter.org/perspectives-papers/israel-uae-peace-protest/ (accessed on 22.11.2020).

Galtung, J. (1973). The European Community: A Superpower in the Making. London: Allen \& Unwin. 
GATT - the General Agreement on Tariffs and Trade (1986). Available at: https://www.wto.org/english/docs_e/legal_e/gatt47.pdf (accessed on 22.11.2020).

Globes (2020). US to Sell F-35 to UAE as Part of Israel Deal. Available at: https://en.globes.co.il/en/article-us-to-sell-f-35-jets-to-uae-as-part-of-israel-deal1001339722 (accessed on 22.11.2020).

Gomez, R. (2003). Negotiating the Euro-Mediterranean Partnership: Strategic Action in EU Foreign Policy?. New York: Routledge. DOI: https://doi.org/10.4324/9781315199771.

Gordon, N. and Pardo, S. (2015). Normative Power Europe and the Power of the Local, Journal of Common Market Studies, 52(2), 416-427. DOI: https://doi.org/10.1111/jcms.12162.

Gozansky, Y. (2012). The Gulf States in a Changing Strategic Environment. INSS Memo no. 116 [Hebrew], 65-70.

Gozansky, Y. (2020). UAE: Proactive in War and Peace. INSS, 19 August 2020 [Hebrew]. Available at: https://www.inss.org.il/he/publication/uae-proactive-in-war-andpeace/ (accessed on 22.11.2020).

Harkov, L. (2020). The Peace Treaties Between the UAE, Bahrein and Israel are Signed. The Jerusalem Post, 16 September 2020. Available at: https://www.jpost.com/middle-east/israel-uae-bahrain-sign-game-changingnormalization-deal-watch-live-642368 (accessed on 22.11.2020).

Israel Ministry of Foreign Affairs (2013a). Israel-Egypt Peace Treaty. Available at: https://mfa.gov.il/mfa/foreignpolicy/peace/guide/pages/israelegypt\%20peace\%20treaty.aspx (accessed on 22.11.2020).

Israel Ministry of Foreign Affairs (2013b). Israel-Jordan Peace Treaty. Available at: https://mfa.gov.il/mfa/foreignpolicy/peace/guide/pages/israeljordan\%20peace\%20treaty.aspx (accessed on 22.11.2020).

Israel Ministry of Foreign Affairs (2013c). Israel-PLO Interim Agreements since 1993. Available at: https://mfa.gov.il/MFA/Aboutlsrael/Maps/Pages/Israel-PLOInterim-Agreements-since-1993.aspx (accessed on 22.11.2020).

Israel Today (2020), 18.9.2020 [Hebrew] Available at: https://www.israelhayom.co.il/article/801621 (accessed on 22.11.2020).

Israel-Europe Research \& Innovation Directorate (2020). Israel Participation in Horizon 2020. Available at: https://www.innovationisrael.org.il/ISERD/contentpage/israelparticipation-horizon-2020 (accessed on 22.11.2020).

Israeli Central Bureau of Statistics (2020). Table D. 4 - Imports and Exports, by Commodity Groups - Jordan. Available at: https://old.cbs.gov.il/www/fr_trade/d4t41.pdf (accessed on 22.11.2020).

Israeli Central Bureau of Statistics (2020a). Gross Domestic Product and Uses of Resources. Available at: https://old.cbs.gov.il/reader/cw_usr_view_SHTML?ID=342 (accessed on 22.11.2020).

Israeli Central Bureau of Statistics (2020b). Table D. 4 - Imports and Exports, by Commodity Groups - Total E.U. Available at: https://old.cbs.gov.il/www/fr_trade/d4t2.pdf (accessed on 22.11.2020).

Israeli Central Bureau of Statistics (2020c). Table D. 4 - Imports and Exports, by Commodity Groups - USA. Available at: https://old.cbs.gov.il/www/fr_trade/d4t27.pdf (accessed on 22.11.2020).

Kahana A. and ILH Staff (2020). Will EU Sanction Israel Over Annexation Plan? Israel Hayom, 5 October 2020. Available at: 
https://www.israelhayom.com/2020/05/10/will-eu-sanction-israel-overannexation-plan/ (accessed on 22.11.2020).

Kofman, E. (2014). Analysis of potential implication of an economic boycott on Israel [Hebrew]. The Knesset's Center for Information and Research. Available at: https://fs.knesset.gov.il/globaldocs/MMM/ff4e6b58-e9f7-e411-80c800155d010977/2_ff4e6b58-e9f7-e411-80c8-00155d010977_11_10368.pdf (accessed on 22.11.2020).

Landau, N. (2020). FULL TEXT: The Israel-UAE-Bahrain Abraham Accords Peace Agreement. HAARETZ, 16 September 2020. Available at: https://www.haaretz.com/middle-east-news/.premium-full-text-the-israel-uaebahrain-abraham-accords-declaration-1.9159509 (accessed on 22.11.2020).

Manners, I. (2002). Normative Power Europe: A Contradiction in Terms? Journal of Common Market Studies, 40(2), 235-58.

Munin, N. (2003). The Honey Trap: use of international trade benefits as triggers for political achievements. State Revenue Administration Report (2002-2003), pp. 467-489. [Hebrew].

Munin, N. (2011). Can Customs Rules Solve Difficulties Created by Public International Law? - Thoughts on the ECJ's Judgment in Brita Case (C-368/08). The Global Trade and Customs Journal, 6(4), 193-207.

Munin, N. (2015). EU Measures Towards Israeli Activities in the Occupied Territories and the BDS: A Diplomatic Achievement or a Pyrrhic Victory?. The Journal of Multidisciplinary Studies, St. Tomas University, Florida, 7(3), 55-75.

Munin, N. (2020). Does Israel Have Eggs? Outbreak, Sapir College's Electronic Journal, 13 April 2020 [Hebrew]. Available at: https://www.sapir-outbreakjournal.org/copy-of-1 (accessed on 22.11.2020).

Munin, N. and Sitbon, O. (2020). Between Normative Power and Soft Power: the Psagot Case Prism, forthcoming.

Nye, J. S. (2009). Get smart: Combining Hard and Soft Power. Foreign affairs, 88(4), $160-163$.

Ociepka, B. (2013). New Members' Public Diplomacy. In: Davis Cross, M. K. and Melissen, J. (eds.), European Public Diplomacy: Soft Power at Work (chap. 3, pp. 39-56). New York, NY: Palgrave Macmillan.

Odenheimer, A. (2020). Netanyahu Says UAE Wealth Fund Interested in Investing in Israel. Bloomberg, 19 August 2020. Available at: https://www.bloomberg.com/news/articles/2020-08-19/netanyahu-says-uaewealth-fund-interested-in-investing-in-israel (accessed on 22.11.2020).

Official NGO Monitor website (2020). Available at: https://www.ngomonitor.org.il/search/?q=+terror+financing (accessed on 22.11.2020).

Official website of the World Trade Organization (2020), available at: www.wto.org (accessed on 22.11.2020).

OJ L 147/3 21.6.2000. Available at: https://eeas.europa.eu/archives/delegations/israel/documents/eu_israel/asso_a gree_en.pdf (accessed on 22.11.2020).

Pakpahan, B. (N.D.). Deadlock in the WTO: What is Next? Available at: https://www.wto.org/english/forums_e/public_forum12_e/art_pf12_e/art19.htm (accessed on 22.11.2020).

Pardos, A. B. and Blanchard, C. M. (2004). CRS Report for Congress: Saudi Arabia Terrorist Financing Issues, 1-25, Available at: https://fas.org/irp/crs/RL32499.pdf (accessed on 22.11.2020). 
Pierini, M. (2020). New Power Struggles in the Mediterranean. Carnegie Europe, 30 July 2020. Available at: https://carnegieeurope.eu/2020/07/30/new-power-strugglesin-mediterranean-pub-82403 (accessed on 22.11.2020).

Rapier R. (2020). The Oil \& Gas Sector Could Already be in Terminal Decline. Oilprice.com, 17 June 2020. Available at: https://oilprice.com/Energy/CrudeOil/The-Oil-Gas-Sector-Could-Already-Be-In-Terminal-Decline.html (accessed on 22.11.2020).

Shery, N. (2020). UAE: Not Being in Touch with Israel Lead Nowhere. DFN, 17 June 2020. [Hebrew]. Available at: https://www.dfn.co.il/article/5509/ (accessed on 22.11.2020).

Smith, M. P. (2006). Soft Power Rising: Romantic Europe in the Service of Practical Europe. World Literature Today, 80(1), 20-23. DOI: https://doi.org/10.2307/40159018.

Tel Aviv and Center Chambers of Commerce (2019). For the First Time we had in Kairo a Seminar to Promote Trade with Egypt. [Hebrew]. Available at: https://www.chamber.org.il/foreigntrade/1094/1100/98041/ (accessed on 22.11.2020).

The Barcelona Process or Euro-Mediterranean Partnership. Available at: https://www.barcelona.com/barcelona_news/the_barcelona_process_or_euro_m editerranean_partnership (accessed on 22.11.2020).

The Israeli Ministry of Economy (2020). Available at: http://www.economy.gov.il/InternationalAffairs/TradePolicyAndAgreements/Bila teralAgreementsDivision/Pages/AgreementsInNegotiations.aspx (accessed on 22.11.2020).

TOI STAFF (2020). Full text of the 'Treaty of Peace' signed by Israel and the United Arab Emirates. Available at: https://www.timesofisrael.com/full-text-of-the-treaty-ofpeace-signed-by-israel-and-the-united-arab-emirates/\#gs.g7hb03 (accessed on 22.11.2020).

Treaties Office Database (2012). Euro-Mediterranean Interim Association Agreement on trade and cooperation between the European Community, of the one part, and the Palestine Liberation Organization (PLO) for the benefit of the Palestinian Authority of the West Bank and the Gaza Strip, of the other part. Available at: https://ec.europa.eu/world/agreements/prepareCreateTreatiesWorkspace/treati esGeneralData.do?step=0\&redirect=true\&treatyld=254 (accessed on 22.11.2020).

WhiteHouse.gov (2020). PEACE TO PROSPERITY. A Vision to Improve the Lives of the Palestinian and Israeli People. Available at: https://www.whitehouse.gov/peacetoprosperity/ (accessed on 22.11.2020).

Wolf, S. (2009). The Mediterranean Dimension of EU Counter-Terrorism. Journal of European Integration, 31(1), 137-156. DOI: https://doi.org/10.1080/07036330802504013.

Worldmeter (2020). Available at: https://www.worldometers.info/worldpopulation/israel-population/ (accessed on 22.11.2020).

Yediot Aharonot, 12 June 2020. Available at: https://www.ynet.co.il/articles/0,7340,L$5746959,00 . h t m l$ (accessed on 22.11.2020). 
